\title{
Entrepreneurial opportunities in the craft- distilling market in South Africa
}

\author{
M. Ungerer ${ }^{1 *}$, S.M. Kruger ${ }^{1}$, S. Vorster ${ }^{1}$ and G. M. Mansfield ${ }^{2}$ \\ ${ }^{1}$ University of Stellenbosch Business School, Bellville, South Africa \\ ${ }^{2}$ The Strategy Institute of South Africa, Durbanville, South Africa.
}

Received 17 November, 2014; Accepted 22 March, 2015

\begin{abstract}
Opportunities for entrepreneurial entry into the craft-distilling product and market domains of the agricultural sector are presented in this study. Although the craft spirits industry in South Africa is currently in its infancy, the study is able to investigate potential entrepreneurial opportunities for such activities in the farming areas of the Western Cape Province. The first part of the study explores the supply side (product-led diversification) of the market. This in turn leads to a better understanding of the current state of the craft-distilling industry, and establishes a base for the survey. An appropriate survey instrument is developed and administered to existing distillers. The subsequent findings confirm the small size of the craft spirits industry. As expected, the small number of active producers generates a limited range of products in a market with established players having strong bargaining power. To perform effectively however, the entrepreneurial craft producer is advised not to compete directly with these players but rather to exploit niche product opportunities created in the premium consumer market segment attracted to handcrafted, locally-produced and customised offerings. By developing products with a competitive positioning of focussed differentiation complementary to the current portfolio of offerings, new market space can be created and new entrants should find attraction.
\end{abstract}

Key words: Craft-distilling, diversification, entrepreneurship, industry analysis, market space, product spread, strategy.

\section{INTRODUCTION}

Managing a portfolio of assets and revenue streams is a robust strategy for farmers exposed to a range of contextual factors outside their direct control. Diversification in the agricultural sector is widely acknowledged as a survival, risk mitigation, revenue enhancement and optimal resource utilisation strategy (Alsos et al., 2003; Meert et al., 2005; Barbieri and Mahoney, 2009; Grande,
2011; Vik and McElwee, 2011). Since the bulk of agricultural products contain some form of sugar or starch that lends itself to fermenting and distilling to produce a range of alcoholic products, including beers, spirits, liqueurs and aperitifs, craft- distilling presents an opportunity to diversify the portfolio of product offerings (Jorgensen, 2010). As a hedge against the cyclical nature

\footnotetext{
*Corresponding a uthor. E-ma il: ma riusu@usb.ac.za. Tel: 0219184218.
} 
of the agricultural sector and to boost revenues, farmers are encouraged to optimally utilise their resources by diversifying their operations and investing in value-add through product beneficiation (Biyase, 2010). One such area for possible diversification is craft-distilling, also referred to as boutique distilling.

There is however a lack of reliable market information on the characteristics of the craft-distilling industry in South Africa.

\section{Entrepreneurship and product diversification}

One way to create new market space is by expanding a portfolio of offerings to include complementary products for which there is demonstrable untapped demand. Essentially this involves market space creation across the boundaries of current product offerings (Kim and Mauborgne, 2005). In Ansoff's (2007) matrix for the product/market portfolio mix, this type of market space creation would be referred to as diversification, where the latter simultaneously involves the introduction of new products and expansion into new market segments.

Notwithstanding the risks, diversification is an established strategy within the agricultural industry. Vik and McElwee (2011: 390-392) identify diversification as a survival strategy for agricultural businesses, where diversification variably involves developing non-agricultural offerings and/or forward and backward integration in the supply chain. Meert et al. (2005: 81-97) also identify diversification as a survival strategy, particularly on marginal farms. They report that a popular and successful form of diversification is structural diversification where farmers channel farm resources into new products or services, including gate sales, participation in farmers markets, on-farm processing or agri-tourism activities. In other instances, survival is not necessarily the primary driver of diversification and the drive is rather entrepreneurial and focused on revenue growth.

Alsos et al. (2003) as well as Barbieri and Mahoney (2009) investigated entrepreneurial activities aimed at sustaining, complementing or growing farming revenues by optimally allocating resources, be they physical assets, intellectual capital or both - and the underlying goals, be they economic or non-economic. In some instances, on-farm diversification also extends beyond product range expansion or beneficiation of current output. Diversification could also venture into new types of service offerings (looking beyond industry boundaries and not only beyond product offerings) such as tourism activities (Grande, 2011).

The majority of studies show that farmers have a desire to maintain their farm-based lifestyle. Whether economic considerations come into play or not, these farmers feel an emotional connection to the land and thus often base new ventures on the resources currently found on the farm.

Effective strategy underpins growth. To understand how entrepreneurs on farms exploit opportunities, the application of strategy perspectives can enhance the analysis. Two such perspectives are the resource-based view (RBV) and the dynamic capability perspectives (DCP) (Alsos et al., 2003; Grande, 2011). The former views a business as a collection of resources, varying in the level of value adding, which provides the basis for developing new strategies and enduring competitive advantages. It suggests that only resources that are 'valuable, rare and inimitable' provide the firm with the potential for superior performance. In the case of the craft distilling market, valuable resources would include methods of hand-crafting and maintaining an adaptable business that is able to respond quickly to market changes. The rare resources include the novelty aspect of products, innovative packaging and label design as well as a flexible production facility. Inimitable resources include the perceived smoothness or taste of products and the fact that these are high-end goods that are locally made.

Consequently, from an RBV perspective, a critical question when developing new business strategies or ventures is how to develop these valuable resources to meet the needs of the market and make the best of the opportunities it presents (Grande, 2011: 222). Through the RBV lens, the company's success relies on its ability to discover, develop and exploit the unique characteristics of its resource base. However, as Grande (2011: 222) emphasises, the RBV lens does not address dynamic processes in the organisation, such as organisational learning, resource procurement or knowledge integration.

A more complete understanding also factors in the dynamic capabilities that a company uses to align it with changing economic environments and to adapt its resources to suit new situations. In short, through the DCP lens, the success of farm diversification strategies relies not only on the type of resources the farmer has at hand, but also on the farmer's ability to apply these resources in innovative ways - in other words, to exploit entrepreneurial and social abilities including sensing, network-building and forming strategic alliances (Grande, 2011). In this context, entrepreneurship and the process of new venture creation play an important role in the establishment of any new business, including those established as part of farm diversification strategies.

The literature suggests that the success of entrepreneurial ventures relies on a number of interrelated 
factors. Most authors (Man and Chan, 2002; Ozgen, 2011; Kim et al., 2010) agreed that, although opportunity recognition is an important first step in any entrepreneurial endeavour, it is not enough to guarantee success. Others (Man and Chan, 2002; Hmieleski and Baron, 2009) state that entrepreneurs should guard against their inherent optimism for an idea, blinding them to its potential failures and they should not underestimate the value of relying on proper planning and evaluation techniques when assessing the potential for success.

\section{Factors influencing entrepreneurial success}

Entrepreneurial success is dependent on several factors. Recent research related to financial entrepreneurial success (Pienaar, 2013) indicates that commercial success is predicated upon the interrelation of three fundamental elements: the financial potential of opportunity, the effectiveness of applied know-how and abilities; and the motivational drive in the face of significant resistance. This study begins with the examination of the potential commercial opportunities of a niche marketing strategy.

\section{Know-how}

The second attribute (Pienaar, 2013) for successful entrepreneurship is the effectiveness of applied knowhow and abilities. An enhanced understanding of the supply side of the craft-distilling industry going beyond current product offerings must address the following questions:

1. What legacy and macroeconomic factors impact the industry?

2. What are the regulatory entry barriers?

3. Who are the current market players and what are their respective market shares?

4. What is the range of products on offer? And the primary production methods in the context of farm diversification?

5. What is the current turnover (volume versus revenue)?

6. How is distribution done?

7. What are the perceived factors of competition in the industry?

In a response to these questions a survey was conducted among a sample of craft-distillers. The findings have relevance not only for entrepreneurs considering market entry but also established farmers wishing to diversify production by entry into the craft spirits industry.
Before reporting on the survey and its findings, a brief overview of what is currently known about the industry and its competitive environment is called for. The Western Cape produces 92 per cent of the country's wine grapes and is home to 493 private wine cellars, 54 producer cellars and 26 producing wholesalers (SAWIS, 2011). In 2010, the industry produced more than 780 million litres of wine for consumption, 39,5 million litres of wine for the production of pot still brandy, and more than 113 million litres of distilling wine used in the production of wine-based spirits such as brandy, fortified wine, commercial liqueurs and industrial products (SAWIS, 2011). Yet, very few wine farms add value by producing their own spirits and the uptake of the opportunity in the broader agricultural community to produce alcohol from crops that contains some form of sugar or starch are negligible (Jorgensen, 2010).

\section{Market factors influencing entrepreneurial behaviour}

The third factor influencing entrepreneurial commercial success (Pienaar, 2013) is the motivational drive when confronted by significant resistance. In the case of craftdistilling the potential entrant should ensure that an objective view is made of the task at hand.

Regulation does not facilitate market entry. Governmental excise duties and controls traditionally made independent craft-distilling illegal (Deacon, 1980). It was only after 1997 that formal deregulation created more market space for independent spirits producers and craft distillers alike (Ewert, 2005). However despite the post-1997 deregulation, the historical legacy concentrated the market into three large players, namely Distell Group Ltd, Edward Snell \& Co Ltd and Diageo Plc who hold $67 \%$ of the market share in 2010 (Datamonitor, 2011: 2,14). These players have become highly diversified in all segments. Their immense resources, market share and power drove brand-building (Datamonitor, 2011: 15). These forces will present significant challenges for an entrant into the liquor market.

A further regulatory issue is the Liquor Act. The regulatory framework for the manufacture, distribution and sale of liquor in South Africa is founded in The National Liquor Act, Act No 59 of 2003, together with provincial liquor legislation (RSA, 2003). The National Liquor Act distinguishes between manufacturers and micro-manufacturers only in terms of production level. Currently, to qualify as a micro-manufacturer, a producer may not exceed two million litres of spirits, 100 million litres of beer, 50 million litres of traditional African beer or four million litres of wine per year. Should a manufacturer exceed the limit in one of the categories, liquor authorities 
will not allow registration as a micro-manufacturer in any of the other categories, regardless of the quantity produced in the second category (RSA, 2004: 19). Furthermore the liquor licence application procedure is complex.

Notwithstanding the regulatory framework, there are factors that may encourage the entrepreneur.

\section{Evolving consumers' preferences}

There is a discernible consumer preference-shift away from mass-produced, mass-marketed spirit brands, towards higher quality, premium products produced by small-scale, private manufacturers (Datamonitor, 2011). This opportunity can enable a private brand to enter the liquor trade and compete more directly in both price and quality with the larger players. This is evidenced by the large number of craft- (or micro-) breweries that have of late become active in the South African beer market (Cape Town Festival of Beer, 2011; Clarens Craft Beer Festival, 2012; Heron, 2012; Holmes, 2012).

Entrepreneurial opportunities exist, yet the craft-spirits trade has been slow to exploit this emerging consumer trend. Nevertheless, new entrants face many poorly understood challenges, including the regulatory and market entry barriers highlighted above.

\section{Objectives}

The purpose of this article is to present survey findings and report on the current state of the craft spirits industry, supporting craft-distilling as a potential diversification strategy for entrepreneurial activity. The Western Cape Province is South Africa's key fruit and grain producing region (Hortgro Services, 2010; Grain SA, 2011). There are opportunities that could favour astute market entrants.

\section{METHOD}

This section describes the market data collection process beginning with an online survey of the current state of the South African craft spirits industry.

Respondents were those who operated a commercial craft-spirits business in South Africa, and who market and distribute their products independently, and express at least the intention to distil and sell their own spirits. The questions included geographic location and size, number of products, and basic production and sales information such as product type, bottle size, sales price and total sales volume.

The bulk of the questions explored (i) perceptions on factors of competition for craft distillers, (ii) the role of social and other media platforms in marketing, (iii) the profitability of the craft spirits industry and its share of overall revenue, (iv) the extent of farm diversification, and $(v)$ the nature of the craft-distilling value chain, including typical value adding processes respondents engaged in.

Through a diligent process that involved, inter alia, web-based research and direct interaction with industry experts, industry bodies and suppliers of distilling equipment, a total population of 36 possible respondents were identified. Of the 36 identified distillers, 32 were contacted personally to complete the survey and 23 respondents eventually completed the survey, representing $63.8 \%$ of the identified population. In most instances, data analysis used point estimators to calculate an estimated population mean for the particular parameter. The calculated confidence level required for a $10 \%$ bound on the error of estimation was $78.89 \%$. This was rounded up to $80 \%$, with the bound on the error of estimation at $10.28 \%$

\section{RESULTS}

The subsequent analysis produced the following results.

Geographical spread - The majority of respondents (16 of the 23) were located in the Western Cape Province.

Product types - Respondents were asked to categorise each of the products they produce into one of 18 categories. This is captured in Figure 1.

Of the 65 different products produced by the sample of craft distillers, 19 products fell in the pot still brandy category, 11 in the husk spirit (or grappa) category and 10 in the mampoer/witblits category. This concentration in four product categories underscores the lack of variation in the industry's current product offering. The remaining 25 products were spread over 10 other categories of spirits, with seven in the liqueur category, five in the gin category, three in each of the Eaux de vie and vodka categories and one in each of the aquavit, rum, spirit aperitif and three whiskey categories.

Sales volume - It was possible to estimate the combined average annual sales volume by multiplying the bottle size of a particular product with the midpoint of the sales volume class of that product. These estimates were then used to calculate a confidence interval for the average annual sales volume per product of each individual product type. Because the population of craft-spirits products is small relative to the sample size, it was necessary to apply a finite population correction factor when calculating the confidence intervals.

Furthermore, because the size of the population of each individual product type is not known, this was estimated by taking the number of products produced by each respondent as a basis to calculate the weighted average number of products per identified producer in the population. This average (which was rounded up to a 


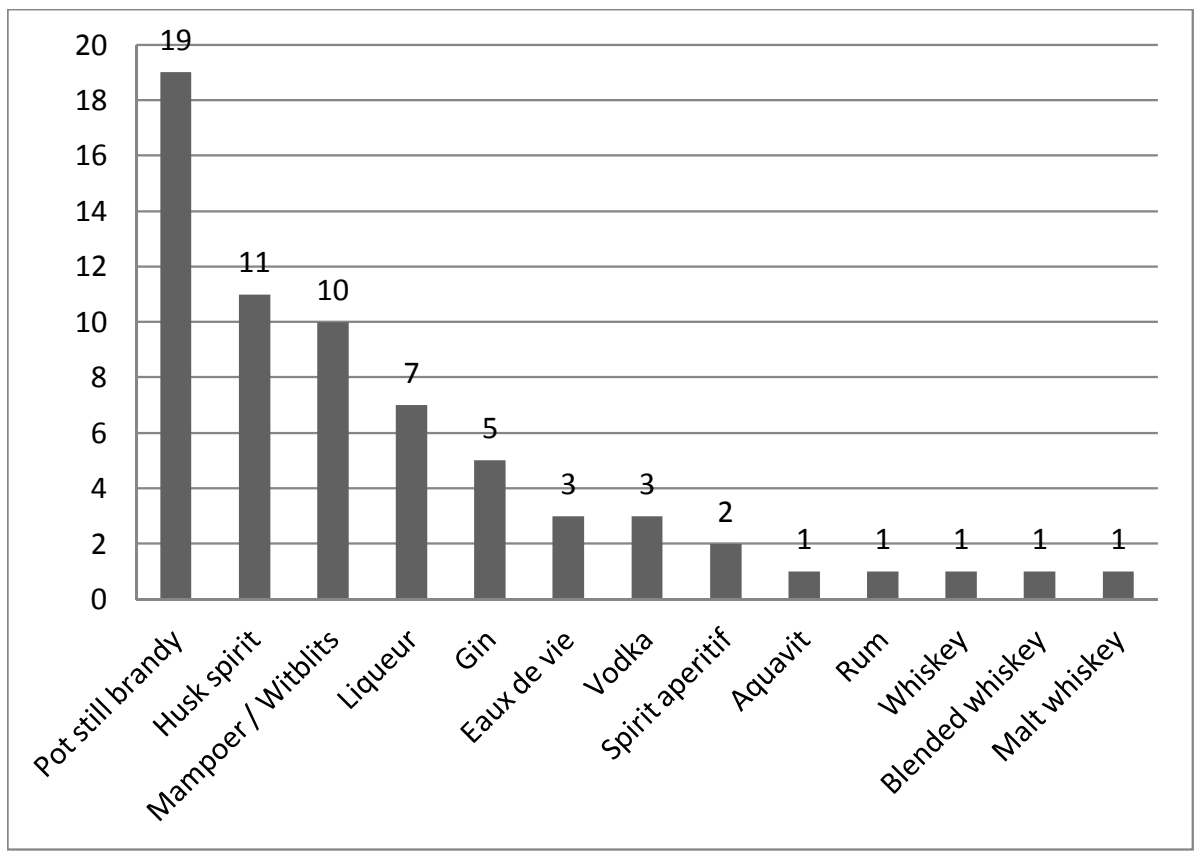

Figure 1. Market segmentation - products by category.

whole number) was then multiplied by the number of producers to estimate the total number of individual products in the population. The previously calculated population proportion of each product type was then applied to the calculated number of products to obtain a total number for products in the population for each product category. The midpoint of the calculated confidence intervals for each product type was then used as a point estimator of the expected average annual sales volume of the population of each type of craft spirits product. The results are captured in Figure 2.

The most important finding is that the estimated total annual sales volume of all craft spirits produced in South Africa currently does not even exceed the maximum two million litres of spirits that may be produced under a micro-manufacturing licence. Stated differently, the entire industry's manufacturing capacity can be accommodated under a single micro-manufacturing licence.

Turnover -To calculate the average annual turnover produced by a particular product, respondents were asked to place the price per bottle (excluding VAT) at which they sell a particular product in one of nine classes [<R50; R50 - R99; R100 - R149; R150 - R199; R200 R249; R250 - R299; R300 - R349; R350 - R400; > $\mathrm{R} 400]$. By following the same procedure described in the previous section, it was possible to estimate the average annual turnover produced by each spirit type. The midpoint of the confidence intervals calculated for each product type was again used as a point estimator of the expected average annual turnover of the population of each type of craft spirits product. The results are captured in Figure 3.

To put Figure 3 into perspective, a comparison was drawn between the anticipated turnover for an individual product of a particular type versus the anticipated total turnover for that product category in the market. This was then superimposed on the anticipated total annual sales volume for each product category on a combined graph, as per Figure 4.

From Figure 4 it is evident that mampoer/witblits, vodka, gin and liqueur products have high anticipated sales volumes relative to their turnover. This implies that many of the products in these categories are being sold at relatively low prices.

When comparing turnover anticipated from an individual product in a particular class to what is expected from the class as a whole, it becomes apparent that individual husk spirit products are anticipated to have a higher annual turnover per product than pot still brandies. However, the husk spirit class as a whole is anticipated to have a lower total annual turnover than pot still brandy.

This implies that, generally speaking, husk spirit producers sell fewer units, but at higher prices, than do pot still brandy producers. The same can be said for spirit aperitif. These products seem to sell at much higher 


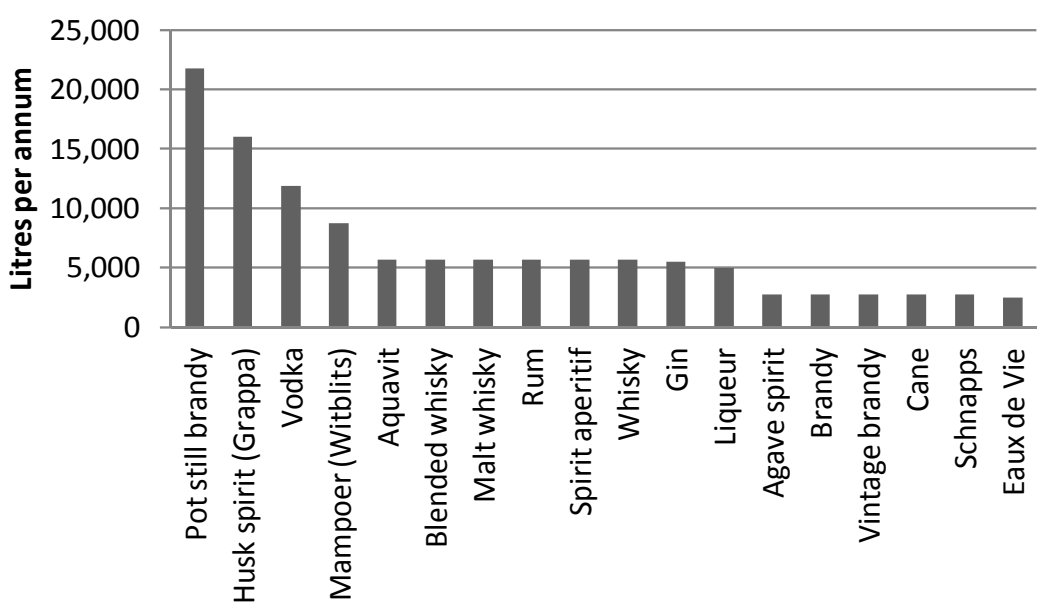

Product type

Figure 2. Estimated average annual sales volume of the population of craft spirits products.

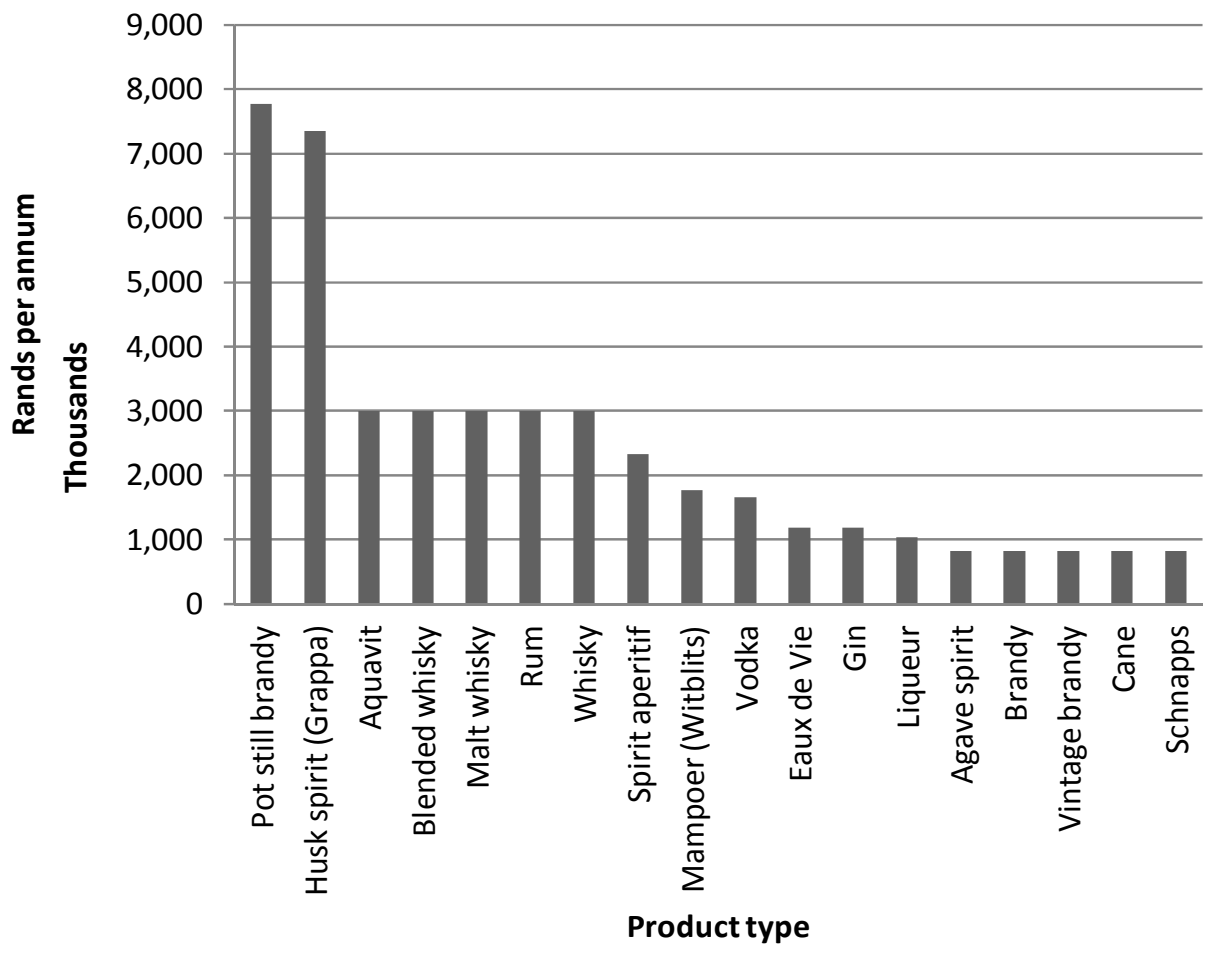

Figure 3. Estimated average annual turnover of population of products.

individual prices than any of the other product classes, although there are very few units being sold in the market as a whole, causing the anticipated total annual turnover for this class of product to be comparatively low.
Production methods - Respondents had to indicate whether or not they ferment their own alcohol and/or distil their own spirits. Although craft-distilling in the purist sense of the word implies a certain combination of skill 


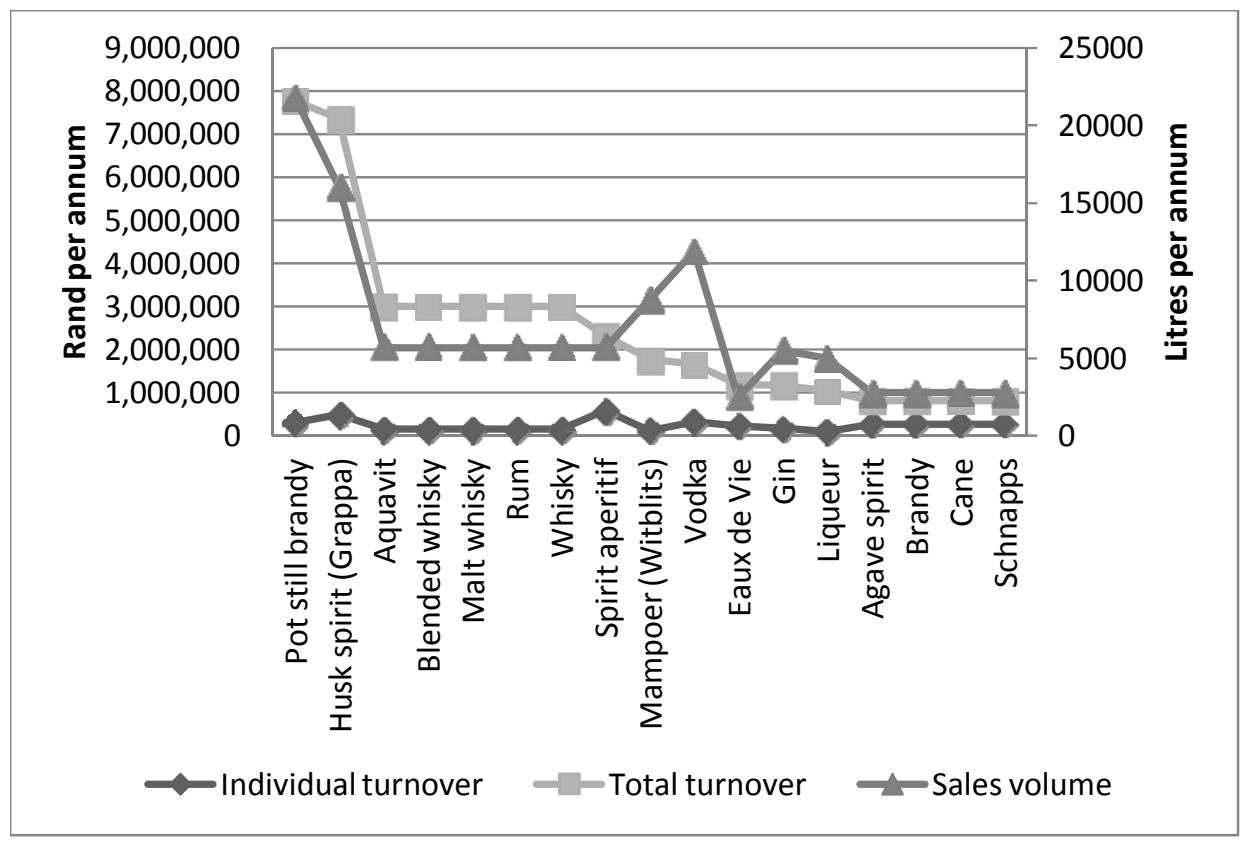

Figure 4. Anticipated turnover versus anticipated sales volume.

and art and hints at the hand-crafted nature of the product, the fact that a producer buys in distilled spirits does not preclude such producer from applying a certain amount of skill and artful expression in the flavouring and blending of the base spirit. By implication, farmers who do not have the necessary resources to ferment and/or distil their own spirits, but have access to other resources such as distinctive herbs or spices, could also partake in craft-distilling diversification opportunities.

The survey nevertheless found that $87 \%$ of respondents fermented their own alcohol and over $95 \%$ distilled their own spirits. Stated differently, the vast majority of sampled independent producers can be considered craft distillers in the purist sense of the word.

Distribution - Respondents were asked to select channels from a list of distribution options where consumers can purchase their products.

It was found that the majority of producers have their own retail stores (online or physical) and that a meaningful number are able to distribute their products through speciality bottle stores. About half are able to distribute their products through bottle stores in their own area. Restaurants, fairs or farmers markets also play a role in getting craft producers' products to market. Hotels and bars however play a minor role, as do national bottle store chains.

It was furthermore found that around $35 \%$ of sampled producers export their products and of these producers, the majority export their goods to Europe, followed by Africa and North America.

Factors of competition - To understand the basis of competition, respondents were asked to choose from a list of pre-coded competitive factors that they believe attract consumers. Respondents could choose three or more alternatives from the following, but had the option of adding additional factors in an open-ended section:

1. Handcrafted methods used in manufacturing products

2. Smoothness or taste of products

3. Products are high-end or luxury goods

4. Products are locally made

5. Novelty aspect of products

6. Innovative package and label design

7. Heritage of production facility

8. Age or aging potential of your products

9. Above-the-line marketing

As summarised in Figure 5, the majority of producers in the sample regard handcrafted production methods as having particular attraction to consumers. Smoothness and taste is also perceived as an important feature, followed by the perception that their products are luxury goods appealing to consumers' high-end lifestyle aspirations. The fact that products are locally made was seen as important in drawing consumers in by ten of the 


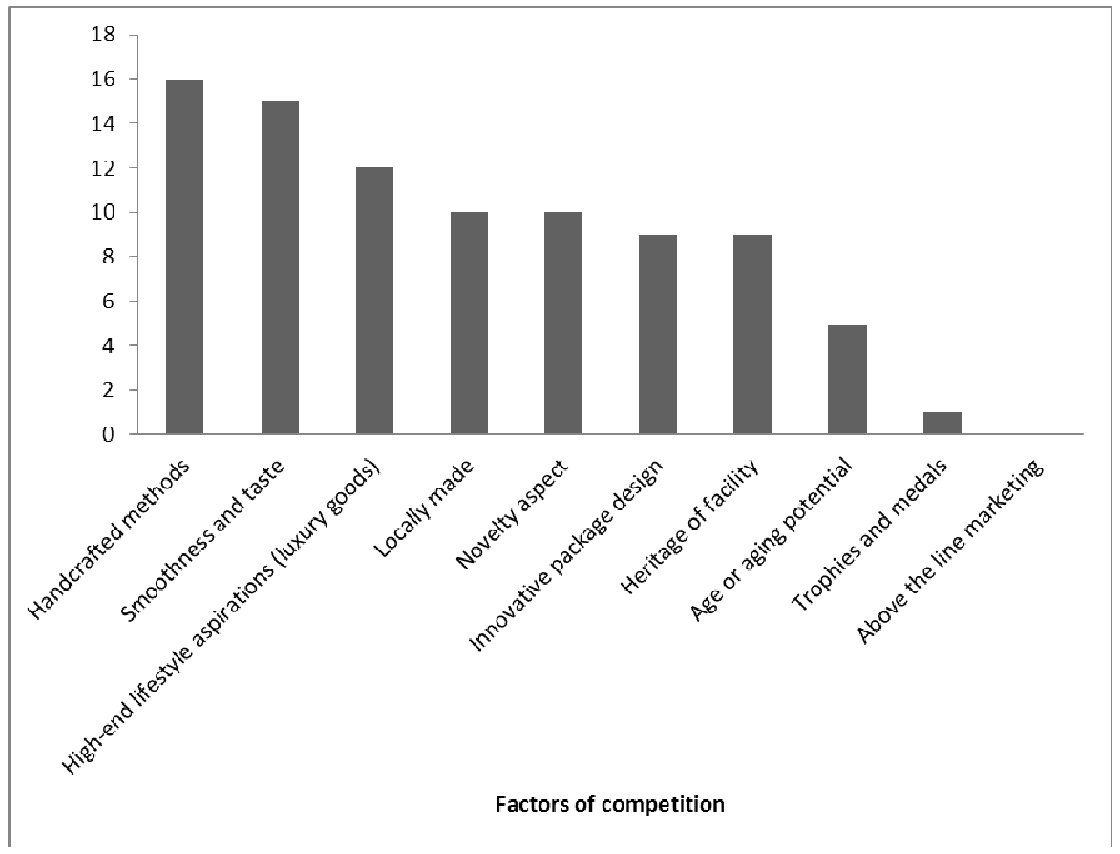

Figure 5. Factors of competition.

23 respondents and just as many producers felt that the novelty aspect of their products is important. Only nine of the 23 sampled producers thought that consumers are attracted by their innovative package design or the heritage of their production facility and only four felt that the age or aging potential of their products appealed to their consumers. Not one producer in the sample felt that an above-the-line marketing had meaningful consumerfacing value. Word-of-mouth and social media thus seem to be more important in terms of marketing.

Farm diversification - Since the research is concerned with craft-distilling as a potential farm diversification strategy, it was deemed necessary to gain an understanding of how many craft-distilling businesses are run as part of a larger farm operation.

It was found that some $96 \%$ of respondents do not derive their main source of income from their distilling business. Other sources of income listed by respondents included winemaking, growing olives, making olive oil, being engaged in mixed farming or external employment, making beer, distributing liquor, running a restaurant, guest house or bar, living off a pension, selling gift cards and growing vegetables.

It was also found that $74 \%$ of respondents operated their distilling businesses from a farm and, of these, $88 \%$ indicated that they owned the farm from which the business is operated. Of the respondents who owned the farm, $73 \%$ indicated that the distilling business supplemented the farm's income and that, as such, their distilling business could be considered a farm diversification initiative (i.e. $47 \%$ of total sample).

In terms of share of inputs, it was found that all of the respondents who own farms grow some of the ingredients on the farm, with $40 \%$ of these respondents indicating that they grow all of the ingredients used in the production of their craft distilled products themselves. When asked what ingredients they grow on the farm, respondents indicated that it was mostly grapes, but also botanicals, peaches, apricots, plumbs, herbs and lemons. Judged by the results of the study, the response to the question of whether craft distilling can be considered as a diversification option must be a yes. There are a variety of products and many different input ingredients. Many diverse options are available to the would-be craft spirits distiller. Furthermore, applying Ansoffs (2007) product/market martix, craft spirits distilling is a new product seeking to go to a select, still to be created, market thus serving as a true diversification option.

\section{Conclusion}

In considering the potential entrepreneurial opportunities for diversification (product and market expansion) in the agricultural sector, and specifically craft-distilling as a 
Table 1. Summary of main findings.

\begin{tabular}{|c|c|c|c|c|c|c|}
\hline \multirow[t]{2}{*}{ Geographical spread } & & \multicolumn{3}{|l|}{ Market segmentation } & \multicolumn{2}{|l|}{ Distribution channels } \\
\hline & & Product categories & $\begin{array}{c}\text { Proportion } \\
\text { of total } \\
\text { population } \\
\text { of } \\
\text { products }\end{array}$ & $\begin{array}{c}\text { Average } \\
\text { annual } \\
\text { sales } \\
\text { volumes } \\
\text { (lit) }\end{array}$ & & \\
\hline Eastern Cape & $2.8 \%$ & Pot still brandy & $22 \%$ & 21,770 & Own store/tasting room & $25 \%$ \\
\hline Free State & $0 \%$ & Husk spirit & $13 \%$ & 16,050 & Speciality bottle stores & $23 \%$ \\
\hline Gauteng & $5.6 \%$ & Mampoer/Witblits & $12 \%$ & 8,762 & Local bottle stores & $13 \%$ \\
\hline Kwazulu Natal & $0 \%$ & Liqueur & $9 \%$ & 4,966 & Restaurants & $11 \%$ \\
\hline Limpopo & $2.8 \%$ & Gin & $6 \%$ & 5,513 & Fairs and farm markets & $11 \%$ \\
\hline Mpumalanga & $2.8 \%$ & Eaux de Vie & $4 \%$ & 2,500 & Hotels & $8 \%$ \\
\hline Northen Cape & $5.6 \%$ & Vodka & $4 \%$ & 11,877 & Bars & $6 \%$ \\
\hline North West & $5.6 \%$ & Spirit aperitif & $3 \%$ & 5,679 & National chain of bottle stores & $4 \%$ \\
\hline Western Cape & $75.0 \%$ & Aquavit & $3 \%$ & 5,679 & Exports & $35 \%$ \\
\hline Production methods & & Rum & $3 \%$ & 5,679 & Africa & $25 \%$ \\
\hline Ferments & $87 \%$ & Whiskey & $3 \%$ & 5,679 & Europe & $67 \%$ \\
\hline Distills & $96 \%$ & Blended whiskey & $3 \%$ & 5,679 & North America & $8 \%$ \\
\hline Farm diversification & & Malt whiskey & $3 \%$ & 5,679 & & \\
\hline \multirow[t]{6}{*}{ Farm diversification strategy } & $75 \%$ & Agave spirit & $2 \%$ & 2,769 & & \\
\hline & & Brandy & $2 \%$ & 2,769 & & \\
\hline & & Vintage brandy & $2 \%$ & 2,769 & & \\
\hline & & Cane & $2 \%$ & 2,769 & & \\
\hline & & Schnapps & $2 \%$ & 2,769 & & \\
\hline & & Total & & 119,357 & & \\
\hline
\end{tabular}

means to create new market space, a number of observations can be made about the supply-side of the craft spirits industry in South Africa. These observations have direct relevance to entrepreneurs that wish to venture into this form of farm diversification.

The legacy of a high degree of bargaining power, brand dominance and monopolised access to distribution channels held by major players in the industry renders distribution to and sales of craft-distilling products in national retail stores very difficult. Furthermore, the high degree of regulation, e.g. zoning and other licensing requirements, in the alcohol industry serves as a barrier to entry.

A number of industry characteristics can be identified from the craft spirits survey. A summary of the main findings are contained in Table 1.

The majority of craft spirits products in South Africa (concentrated in the Western Cape Province) currently fall into only four product types, indicating a lack of product/market portfolio diversification.

Many products currently on offer have high anticipated sales volumes relative to their turnover, which points to rather undifferentiated products being sold at relatively low prices. In terms of total sales volume, the craft spirits industry is currently so small that the combined production can be accommodated under a single micromanufacturing licence. There seems to be substantial room for growth within the industry - assuming demand stimulation and successful diversification beyond the portfolio of products currently on offer. In Ansoff's (2007) product/market portfolio mix matrix, diversification of this kind would involve both product and market expansion. Market space would be created through innovation beyond the boundaries of current product offerings, in other words, by diversifying into a complementary product offering namely craft-distilling, thereby exploiting untapped demand (Kim and Mauborgne, 2005). Entrepreneurship would be a key enabler towards successful diversification.

In terms of farm diversification, the survey found that, of the respondents who owned their farms, 73\% indicated that the distilling business supplemented the farm's income. As such, their distilling business could be considered a farm diversification initiative (i.e. $47 \%$ of 
Table 2. Industry issues and trends.

\begin{tabular}{|c|c|c|}
\hline \multicolumn{3}{|c|}{ Industry trends } \\
\hline Industry driving force & Impact & Opportunity / Threat \\
\hline $\begin{array}{l}\text { Bargaining power of large players in the } \\
\text { mass-market industry }\end{array}$ & $\begin{array}{l}\text { Limits craft producers' ability to distribute their products } \\
\text { effectively }\end{array}$ & $\begin{array}{l}\text { Threat: Distribution in } \\
\text { national stores problematic }\end{array}$ \\
\hline High degree of regulation & $\begin{array}{l}\text { Start-up phase time consuming due to licensing } \\
\text { requirements }\end{array}$ & Threat: Long start-up phase \\
\hline Minimum alcohol requirements & $\begin{array}{l}\text { Inhibits international appeal of craft products } \\
\text { Inhibits development of local market }\end{array}$ & $\begin{array}{l}\text { Threat:_Limited possibility for } \\
\text { export } \\
\text { Threat: Limited local market }\end{array}$ \\
\hline $\begin{array}{l}\text { The majority of products fall into four } \\
\text { product categories }\end{array}$ & $\begin{array}{l}\text { There is very little variation in terms of the types of craft } \\
\text { spirits products available in the market }\end{array}$ & $\begin{array}{l}\text { Opportunity: } \\
\text { Create new types of product } \\
\text { offerings }\end{array}$ \\
\hline $\begin{array}{l}\text { Low sales volumes relative to micro- } \\
\text { manufacturing licence restrictions }\end{array}$ & Under-developed product segment & $\begin{array}{l}\text { Opportunity: } \\
\text { Substantial room for growth } \\
\text { Opportunity: }\end{array}$ \\
\hline $\begin{array}{l}\text { Producers currently only export to three } \\
\text { world regions }\end{array}$ & Many untapped export markets & $\begin{array}{l}\text { Export to emerging markets } \\
\text { such as China }\end{array}$ \\
\hline
\end{tabular}

total sample). Yet, reliance on income from craft-distilling is relatively small. The most important distribution channels are own retail stores; speciality bottle stores; and restaurants, fairs or farmers markets. Only $35 \%$ of the sampled craft spirits producers export their products and those that do, export to only three world regions, leaving many export markets untapped. The key competitiveness factors perceived by craft distillers as differentiating their products in the market are: handcrafted production methods; smoothness and taste; the luxury goods nature appealing to consumers' highend lifestyle aspirations, and that it is locally made.

The above issues and trends are summarised in Table 2 , with threats and opportunities indicated.

The key factors of competitive advantage most commonly selected by respondents were:

\section{Handcrafted methods used in manufacturing products \\ 2. Smoothness or taste of products \\ 3. Products are high-end or luxury goods \\ 4. Products are locally made}

On balance, it is clear that the craft spirits industry in South Africa is in its infancy. The small number of producers active in the market generates a limited range of products. With the strong bargaining power exerted by mass-market producers, craft producers would be ill advised to try to compete directly with these players. They should ideally develop a niche product aimed at a premium consumer market segment interested in customised offerings of a handcrafted, locally-produced nature with a discerning taste and smoothness.

The focus in this article is supply-side (product) led diversification. Further demand-side market research to complement a 'blue oceans' strategy innovation process (Kim and Mauborgne 2005) are required to fully understand the opportunities highlighted above, not least the overall competitive positioning, the to-be targeted consumer segments, the appropriate product mix and key elements of a marketing and distribution strategy.

\section{REFERENCES}

Alsos GA, Ljunggren E, Pettersen LT (2003). 'Farm-based entrepreneurs: what triggers the start-up of new business activities?' J. Small Bus. Enterp. Dev. 10(4):435-443.

Ansoff IH (2007). Strategic Management. New York: Palgrave Macmillan.

Barbieri C, Mahoney E (2009). 'Why is diversification an attractive farm adjustment strategy? Insights from Texas farmers and ranchers'. Journal of Rural Studies, 25, 58-66.A\&T Consulting, 2005. Industry study: The South African liquor industry. s.I.:s.n.

Biyase L (2010). Farms can be tourist attractions. Sunday Times, 19 September, p. 7.

Cape Town Festival of Beer (2011). Cape Town Festival of Beer. [Online] Available at: http://capetownfestivalofbeer.co.za/ [Accessed 23 January 2012].

Clarens Craft Beer Festival (2012). Brewers and Beers. [Online] Available at: http://www.clarensbeerfestival.co.za/brewers [Accessed 23 February 2012].

Datamonitor (2011). Industry profile: Spirits in South Africa. s.I.:s.n

Deacon IB (1980). The South African liquor industry - Structure, conduct, performance and strategies for future action. Stellenbosch: University of Stellenbosch (PhD Thesis).

Ewert J (2005). 'How competitive is South Africa? Advances and 
challenges in the transformation of the Cape wine industry', Les Cahiers d'Outre-Mer, no. 231-232, July-October, pp. 371-396.

Grain SA (2011). Production info: Area grown, yields and estimates. [Online] Available

http://www.grainsa.co.za/body.php?mostvisited=1\&quicklinkgroupid= $245 \&$ subcatid $=102 \&$ pagetitle=Production $\% 20$ Info\&pagesubtitle $=$ TOT ALE\%20OPPERVLAKTE,\%20OPBRENGSTE\%20EN\%20SKATTIN GS\%20/\%20AREA\%20GROWN,\%20YIELDS\%20AND\%20ESTIMAT ES [Accessed 8 January 2012].

Grande J (2011). 'New venture creation in the farm sector - Critical resources and capabilities'. J. Rural Stud. 27, 220-233.

Heron M (2012). Hip new hops. [Online] Available at: http://www.countrylife.co.za/index.php?p[IGcms_nodes][IGcms_node sUID] $=9 c 9618 c f 887 c e a 08 e 4 f 7 e 704 a 4 c 5 d 3 a 9$ [Accessed 16 March 2012].

Hmieleski KM, Baron RA (2009). 'Entrepreneurs' optimism and new venture performance: A social cognitive perspective', Acad. Manage. J. 52(3): 473-488

Holmes R (2012). Howzit brew. Food and Home Magazine, March, pp. 108-111.

Hortgro Services (2010). Key deciduous fruit statistics 2010: Maps. [Online]

Available

at: http://www.hortgro.co.za/index.php?option=com_content\&view=articl e\&id=151\& Itemid $=157$

[Accessed 8 January 2012].

Jorgensen $\mathrm{R}$ (2010). Learning the distillation process. Wellington, s.n.

Kim WC, Mauborgne R (2005). Blue Ocean Strategy. First eBook Edition ed. Boston: Harvard Business School Publishing Corporation.

Kim JN, Clelland I, Bach S (2010). 'Entrepreneurs as parallel processors: An examination of a cognitive model of new venture opportunity evaluation', Acad. Entrepreneurship J. 16(2):57-85.
Man TW, Chan TL (2002). 'The competitiveness of small and medium enterprises: A conceptualization with focus on entrepreneurial competencies', J. Bus. Venturing, 17:123-142.

Meert H, Van Huylenbroeck G, Vernimmen T, Bourgeois M, Van Hecke, E (2005). 'Farm household survival strategies and diversification on marginal farms', J. Rural Stud. 21: 81-97.

Pienaar E (2013). The most prevalent features impacting on significant financial success amongst repeat entrepreneurs. Unpublished thesis. Stellenbosch: University of Stellenbosch.

Republic of South Africa (RSA) (2003). Liquor Act, No 59 of 2003. Pretoria: Government Printer [Laws].

Republic of South Africa (RSA) (2004). Regulations for the registration of liquor manufacturers and distributors, and related matters under the Liquor Act, 2003. Government Gazette, 17 August, 1-35.

SAWIS (2011). South African Wine Industry Statistics (No 35). [Online] Available at: http://www.sawis.co.za/info/annualpublication.php [Accessed 9 February 2012].

Vik J, McElwee G (2011). 'Diversification and the Entrepreneurial Motivations of Farmers in Norway', J. Small Bus. Manage. 49(3): 390410 